Review Article

\title{
Diagnosing Perioperative Cardiovascular Risks in Noncardiac Surgery Patients
}

\author{
Panpan Li, ${ }^{1}$ Ying Lei, ${ }^{2}$ Qiaomei Li, ${ }^{3}$ Thangavel Lakshmipriya, ${ }^{4}$ Subash C. B. Gopinath $\mathbb{D}^{4,5}$ \\ and Xinwen Gong $\mathbb{1}^{6}$ \\ ${ }^{1}$ Department of Encephalopathy, Ankang Traditional Chinese Medicine Hospital, No. 47, Bashan East Road, Hanbin District, \\ Ankang City, Shaanxi Province 725000, China \\ ${ }^{2}$ Department of Functional (ECG Room), Ankang Traditional Chinese Medicine Hospital, No. 47, Bashan East Road, \\ Hanbin District, Ankang City, Shaanxi Province 725000, China \\ ${ }^{3}$ Operating Room, Ankang Traditional Chinese Medicine Hospital, No. 47, Bashan East Road, Hanbin District, Ankang City, \\ Shaanxi Province 725000, China \\ ${ }^{4}$ Institute of Nano Electronic Engineering, Universiti Malaysia Perlis, 01000 Kangar, Perlis, Malaysia \\ ${ }^{5}$ School of Bioprocess Engineering, Universiti Malaysia Perlis, 02600 Arau, Perlis, Malaysia \\ ${ }^{6}$ Department of Cardiology, Ankang Traditional Chinese Medicine Hospital, No. 47, Bashan East Road, Hanbin District, \\ Ankang City, Shaanxi Province 725000, China
}

Correspondence should be addressed to Xinwen Gong; akeygxw@sina.com

Received 16 April 2019; Accepted 16 June 2019; Published 25 August 2019

Guest Editor: Jie Zhou

Copyright (C) 2019 Panpan Li et al. This is an open access article distributed under the Creative Commons Attribution License, which permits unrestricted use, distribution, and reproduction in any medium, provided the original work is properly cited.

Every year, over 200 million adults are undergoing noncardiac surgery. These noncardiac surgery patients may face the risk of cardiac mortality and morbidity during the perioperative and recovery periods. Around ten million patients who underwent noncardiac surgery experience cardiac complications within the first 30 days of the postoperative period; the complications are myocardial infarction, cardiac death, and cardiac arrest. This cardiovascular risk is mostly faced by the patients having cerebrovascular or cardiac disease and the patients with the age greater than 50 years. Monitoring and treating cardiac diseases with a suitable biomarker during the perioperative period is necessary for the early recovery of noncardiac surgery patients. This review discussed the risk factors and the key guidelines to avoid the cardiovascular risks during the perioperative period of noncardiac surgery patients. In addition, the biomarkers and identification strategies for cardiac diseases are discussed.

\section{Introduction}

In the past, over 50 million surgeries have been performed every year in America; among them, $1.4-3.9 \%$ of patients are facing the complications by cardiac issues [1]. Other surgery cases in the rest of the world are also showing the similar problems, and the mandatory urging attempts have been made to overcome the above issues. Among these, analyzing the cardiovascular risks during the perioperative period of noncardiac surgery patients is the common clinical practice to take care of the associated cardiovascular problems by the anesthesiologist, medical consultant, and surgeon [2]. This practice involves managing and detecting cardiovascular diseases and predicting the long and short periods with cardiovascular risks [3]. In particular, the analyses are necessary for the patients with the age above 50 years and the patients already having the cardiovascular problems owing to the pulmonary edema, acute myocardial infarction, and primary cardiac death [4]. So far, ischemic heart disease for noncardiac surgery patients during the preoperative evaluation is the most common cardiac issue. The goal of analyzing preoperative cardiovascular risk management is to develop a patient's good health. In this review, the authors discussed the possible reasons of cardiovascular risks during noncardiac surgery and assessed the clinical issues during the preoperative period, biomarkers for preoperative 
analyses, and guidelines and recommendations for the preoperative cardiovascular risk assessment.

\section{Reasons for Increasing Risks and Causes of Risks Associated with Surgery}

The cardiovascular risks are much higher in the patients having cardiovascular-related problems. These risks are depending on various factors including the patients with cardiovascular history, fluid exchanges, and the type of anesthesia $[5,6]$. It has been found that with a patient there were postoperative cardiovascular complications such as atrial fibrillation. In particular, the risk is connected with coronary artery disease [7]; in addition, obesity increases cardiovascular risks. The patients with obesity have increased risk of an adverse cardiovascular problem during the period of noncardiac surgery [8].

Age is also considered as one of the important factors for cardiovascular risks during the time of noncardiac surgery. Patients aged above 55 years with cardiovascular disease/ cerebrovascular disease and diabetes will have more risk of different cardiovascular-related problems such as heart failure, valvular heart disease, myocardial infarction, and pulmonary vascular disease. The patients with the age above 62 years have the enhanced risk of perioperative stroke. For the age above 65 years, there was an evidenced report showing the risk of acute ischemic stroke while undergoing noncardiac surgery. Obviously, patients over the age of 70 years are facing lots of postoperative complications [9].

Heart failure is one of the major perioperative risks during noncardiac surgery [10]. Hammill et al. [10] concluded that patients having coronary artery disease and heart failure are facing the highest risk during noncardiac surgery. Patients with distended jugular veins or third sound at the preoperative examination show the high risk of postoperative pulmonary edema. The risk is higher in the patients who have the left ventricular dysfunction, asymptomatic cardiac stress, ischemic heart disease and arrhythmias, and valvular heart disease [11]. In addition, also the patients with the record of congestive heart failure during the chest roentgenogram have the risk of perioperative pulmonary edema [12-14]. It was found that the patients with heart failure have the minor ambulatory. Unfortunately, a death rate of $4.8 \%$ is with the nonischemic heart failure cases compared to $0.8 \%$ of the coronary artery disease patients [15].

\section{Assessing Clinical Data for Perioperative Evaluation}

The patient's history with the physical examination reveals the possible risk factors for pulmonary, cardiac, and infectious diseases, and the analysis on the functional capacity of the patients is considered as the perioperative evaluation [16]. The patient's medical record and clinical data are investigated to monitor the basic function of the heart. The normal healthy man has a properly functioning heart with a good bloodstream (Figure 1). Basic laboratory tests including chest X-ray, body mass index, blood test, and electrocardiography (ECG) have been recorded before the four weeks of the surgery. The assessment on diastolic and systolic dysfunctions is the supporting measurement for the above tests (Figure 2(a)). ECG is one of the very common practices to monitor cardiac failure as the preliminary test (Figure 2(b)). In addition, the functional capacity of the patients has been analyzed by a spectrum with the daily activities.

\section{Biomarkers for Perioperative Evaluation}

Even though the risk factors for cardiovascular disease have been found to be decreased recent years, most of the deaths $(\sim 50 \%)$ are caused due to the cardiovascular complaints in the patients already having the history of cardiovascular problems [17]. To overcome this issue, it is mandatory to use the suitable cardiac-specific biomarkers towards the diagnosis. Analysis on these biomarkers helps to reveal the problems associated with the heart muscle, myocardial stress, apoptosis, and neurohormonal pathways. The predominant and common biomarkers are CK-MB (creatine kinase-MB) isoenzyme, CK (creatine kinase), AST (aspartate aminotransferase), HDBH (hydroxyl butyrate dehydrogenase), LDH (lactate dehydrogenase), TnT (troponin $\mathrm{T}$ ), TnI (troponin I), and myoglobin. Developing a novel biomarker is mandatory to avoid the cardiovascular risks during the perioperative period. Karp [18] has analyzed the biomarkers with 2054 noncardiac surgery patients; it has been found that N-terminal pro-B-type natriuretic peptide (NTproBNP) and C-reactive protein (CRP) were independent and strong biomarkers for the perioperative cardiovascular risk event. It was found that using NT-BNP, it is possible to predict the major cardiovascular risks or deaths in the patients having heart failure and coronary artery disease [19]. With CRP marker-associated perioperative cardiovascular risks, huge cohort of patients are undergoing a major elective noncardiac surgery [20]. An elevated level of troponin has also been found to be an indication of cardiovascular risk [21]. Another research has found that the increasing level of troponin was noticed in patients who are undergoing leg amputation with chronic peripheral arterial vascular disease [22] and in the patients having the history of chronic critical limb ischaemia [23]. In addition, hsTnT (high-sensitive troponin), hFABP (heart-type fatty acid-binding protein), miRNA (microRNA), and MR-PAMAP (midregional fragment of proadrenomedullin) were also used as the biomarkers for cardiovascular risk monitoring [24].

\section{Diagnosing Cardiovascular Risk-Associated Biomarkers by Biosensors}

Using the above biomarkers, several sensing strategies have been generated in the past for cardiac diseases [25-28], based on the labelling and label-free strategies (Figure 3). Table 1 summarizes the detection strategies using different cardiovascular biomarkers against the appropriate probe molecules. These sensing systems are mainly operating based on the transducer as stated elsewhere, in which the probe (receptor) molecule has been immobilized on the sensing 


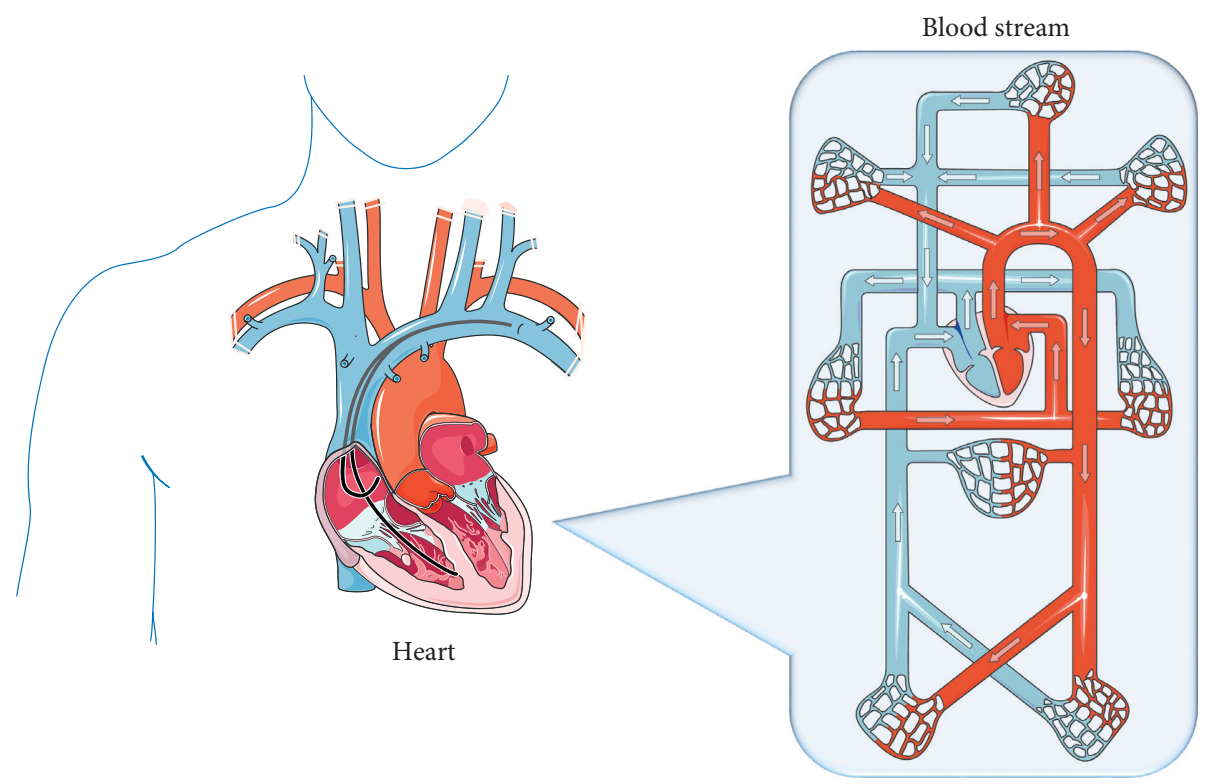

Figure 1: Overview of the human heart and the blood streaming system.
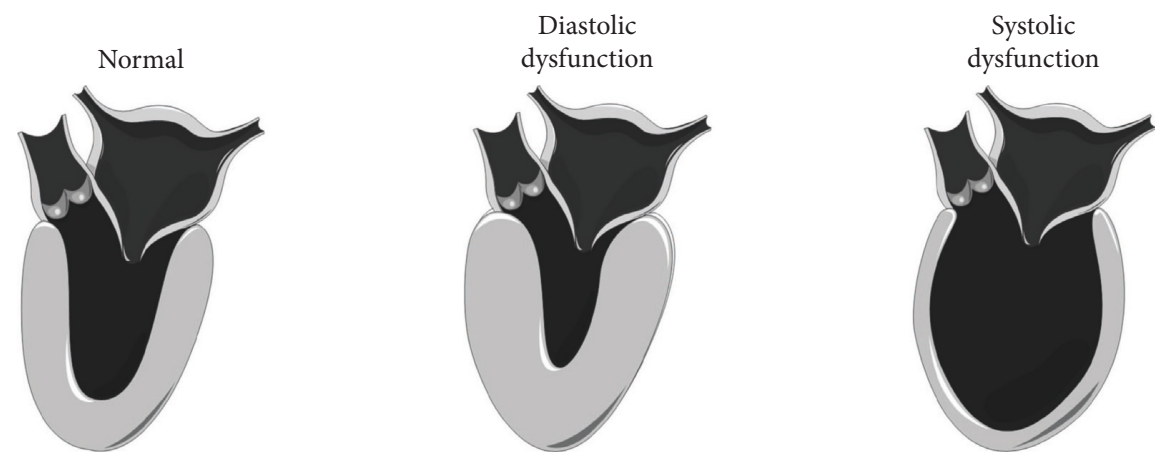

(a)
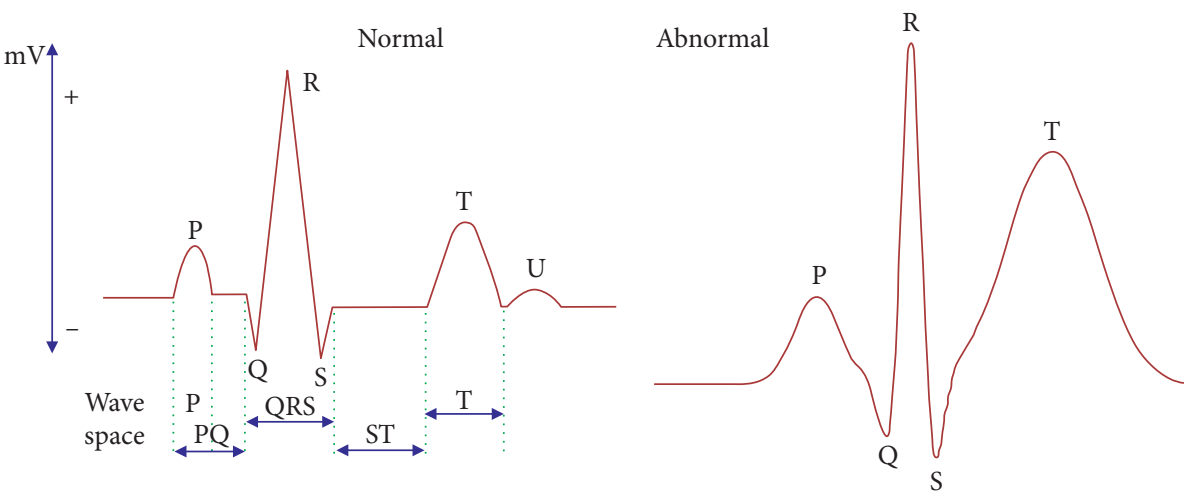

(b)

Figure 2: System correlation with the heart. (a) Normal, diastolic, and systolic dysfunction of the heart. (b) Normal and abnormal electrocardiograms.

surface to interact the analyte in the sample(s) to be analyzed. The transducer will convey the binding events, and it can be interpreted by the signal output (Figure 4) [37-43]. For detecting the cardiac biomarkers, the similar strategies have been followed and well demonstrated [25-28]. These biosensing systems can be used to survey the cardiovascular risks during noncardiac surgery. Different biosensors including surface plasmon resonance, electrochemical sensor, polymerase chain reaction, enzyme-linked immunosorbent assay, colorimetric analysis, and RAMAN spectroscopy were 


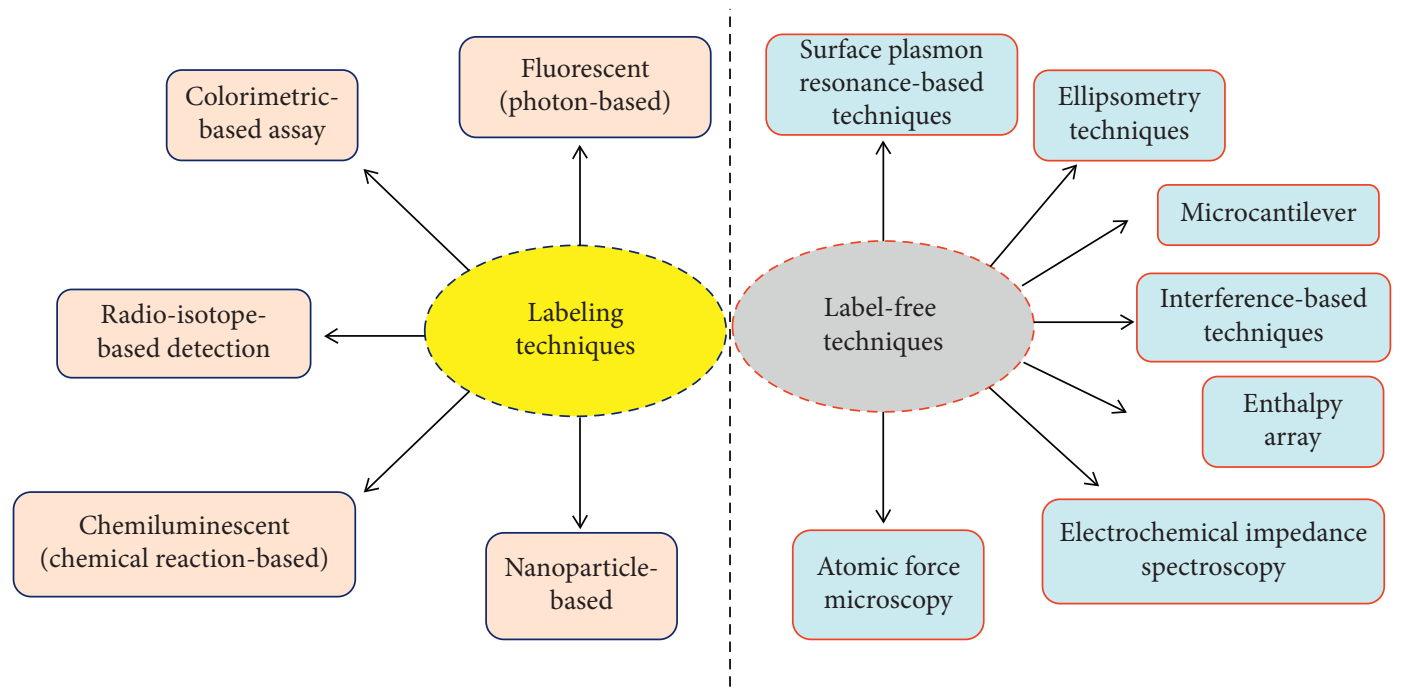

FIgURE 3: Strategies with biosensors. Different sensing systems with labelling and label-free strategies are displayed.

TABLE 1: Biomarker-associated measurements, risk factors, and guidelines.

\begin{tabular}{|c|c|c|c|c|c|c|c|}
\hline Biomarker & Risks & Measurement & Probe & $\begin{array}{l}\text { Limit of } \\
\text { detection }\end{array}$ & $\begin{array}{c}\text { Advantage/ } \\
\text { disadvantage }\end{array}$ & Clinical guide & Reference \\
\hline $\mathrm{BNP}^{*}$ & $\begin{array}{l}\text { Decrease in blood } \\
\text { pressure }\end{array}$ & Immunofluorescent & Antibody & $400 \mathrm{pg} / \mathrm{L}$ & $\begin{array}{l}\text { Comparatively less } \\
\text { sensitive }\end{array}$ & $\begin{array}{c}\text { Monitor carefully } \\
\text { with heart surgery } \\
\text { patients }\end{array}$ & [29] \\
\hline NT-proBNP & $\begin{array}{l}\text { Decrease in blood } \\
\text { pressure }\end{array}$ & Immunofluorescent & Antibody & $10 \mathrm{ng} / \mathrm{L}$ & $\begin{array}{l}\text { Good marker for } \\
\text { surgery patients }\end{array}$ & $\begin{array}{c}\text { Monitor carefully } \\
\text { with heart surgery } \\
\text { patients }\end{array}$ & [29] \\
\hline ProBNP & $\begin{array}{l}\text { Decrease in blood } \\
\text { pressure }\end{array}$ & Immunofluorescent & Antibody & $3 \mathrm{ng} / \mathrm{L}$ & $\begin{array}{l}\text { Good marker for } \\
\text { surgery patients }\end{array}$ & $\begin{array}{c}\text { Monitor carefully } \\
\text { with heart surgery } \\
\text { patients }\end{array}$ & [29] \\
\hline Troponin I & Heart attack & Electrochemical & Aptamer & $\begin{array}{l}30 \mathrm{pg} / \\
\mathrm{mL}\end{array}$ & Standard biomarker & $\begin{array}{l}\text { Treatment for } \\
\text { cardiac muscle } \\
\text { damage }\end{array}$ & {$[30]$} \\
\hline Troponin $\mathrm{T}$ & $\begin{array}{l}\text { Contraction of } \\
\text { skeletal and heart } \\
\text { muscle and } \\
\text { myocardial injury }\end{array}$ & Electrochemical & Antibody & $1 \mathrm{pg} / \mathrm{mL}$ & Standard biomarker & $\begin{array}{l}\text { Treatment for } \\
\text { cardiac muscle } \\
\text { damage }\end{array}$ & {$[31]$} \\
\hline $\begin{array}{l}\text { C-reactive } \\
\text { protein }\end{array}$ & $\begin{array}{l}\text { Inflammation } \\
\text { in the arteries } \\
\text { of the heart. }\end{array}$ & $\mathrm{SPR}^{* *}$ & Antibody & $\begin{array}{l}10 \mathrm{pg} / \\
\mathrm{mL}\end{array}$ & $\begin{array}{l}\text { Best target to predict } \\
\text { the mortality with } \\
\text { other markers. }\end{array}$ & $\begin{array}{c}\text { Controlled diet } \\
\text { and cholesterol } \\
\text { level }\end{array}$ & {$[32]$} \\
\hline Troponin I & Heart attack & Electrochemical & Antibody & $1 \mathrm{pg} / \mathrm{mL}$ & Standard biomarker & $\begin{array}{l}\text { Treatment for } \\
\text { cardiac muscle } \\
\text { damage }\end{array}$ & [31] \\
\hline $\begin{array}{l}\text { C-reactive } \\
\text { protein }\end{array}$ & $\begin{array}{c}\text { Inflammation } \\
\text { in the arteries } \\
\text { of the heart }\end{array}$ & SPR & Aptamer & $10 \mathrm{pM}$ & $\begin{array}{l}\text { Comparatively less } \\
\text { sensitive }\end{array}$ & $\begin{array}{l}\text { Controlled diet } \\
\text { and cholesterol } \\
\text { level }\end{array}$ & {$[33]$} \\
\hline $\begin{array}{l}\text { C-reactive } \\
\text { protein }\end{array}$ & $\begin{array}{l}\text { Inflammation } \\
\text { in the arteries } \\
\text { of the heart }\end{array}$ & Voltammetry & Antibody & $10 \mathrm{fM}$ & $\begin{array}{l}\text { High-sensitive. } \\
\text { Biomarker for } \\
\text { perioperative } \\
\text { cardiovascular risk }\end{array}$ & $\begin{array}{l}\text { Controlled diet } \\
\text { and cholesterol } \\
\text { level }\end{array}$ & {$[34]$} \\
\hline $\begin{array}{l}\text { Lactate } \\
\text { dehydrogenase }\end{array}$ & Tissue damage & Amperometric & $\begin{array}{l}\text { Aptamer } \\
\text { and } \\
\text { antibody }\end{array}$ & $1 \mu \mathrm{M}$ & $\begin{array}{l}\text { High specificity due } \\
\text { to the aptamer }\end{array}$ & $\begin{array}{l}\text { Treatment for } \\
\text { enzyme regulation }\end{array}$ & {$[35]$} \\
\hline $\begin{array}{l}\text { High } \\
\text { sensitivity } \\
\text { troponin }\end{array}$ & Future heart attack & $\begin{array}{l}\text { Electron mobility } \\
\text { transistor }\end{array}$ & $\begin{array}{l}\text { Aptamer } \\
\text { and } \\
\text { antibody }\end{array}$ & $6 \mathrm{pg} / \mathrm{mL}$ & $\begin{array}{l}\text { High specificity due } \\
\text { to the aptamer }\end{array}$ & $\begin{array}{l}\text { Treatment for } \\
\text { cardiac muscle } \\
\text { damage }\end{array}$ & {$[36]$} \\
\hline $\mathrm{BNP}$ & $\begin{array}{l}\text { Decrease in blood } \\
\text { pressure }\end{array}$ & Electrochemical & Antibody & $1 \mathrm{pg} / \mathrm{mL}$ & $\begin{array}{l}\text { Good marker for } \\
\text { surgery patients }\end{array}$ & $\begin{array}{c}\text { Monitor carefully } \\
\text { with heart surgery } \\
\text { patients }\end{array}$ & [31] \\
\hline
\end{tabular}

${ }^{*}$ B-type natriuretic peptide (BNP); ${ }^{* *}$ surface plasmon resonance (SPR). 


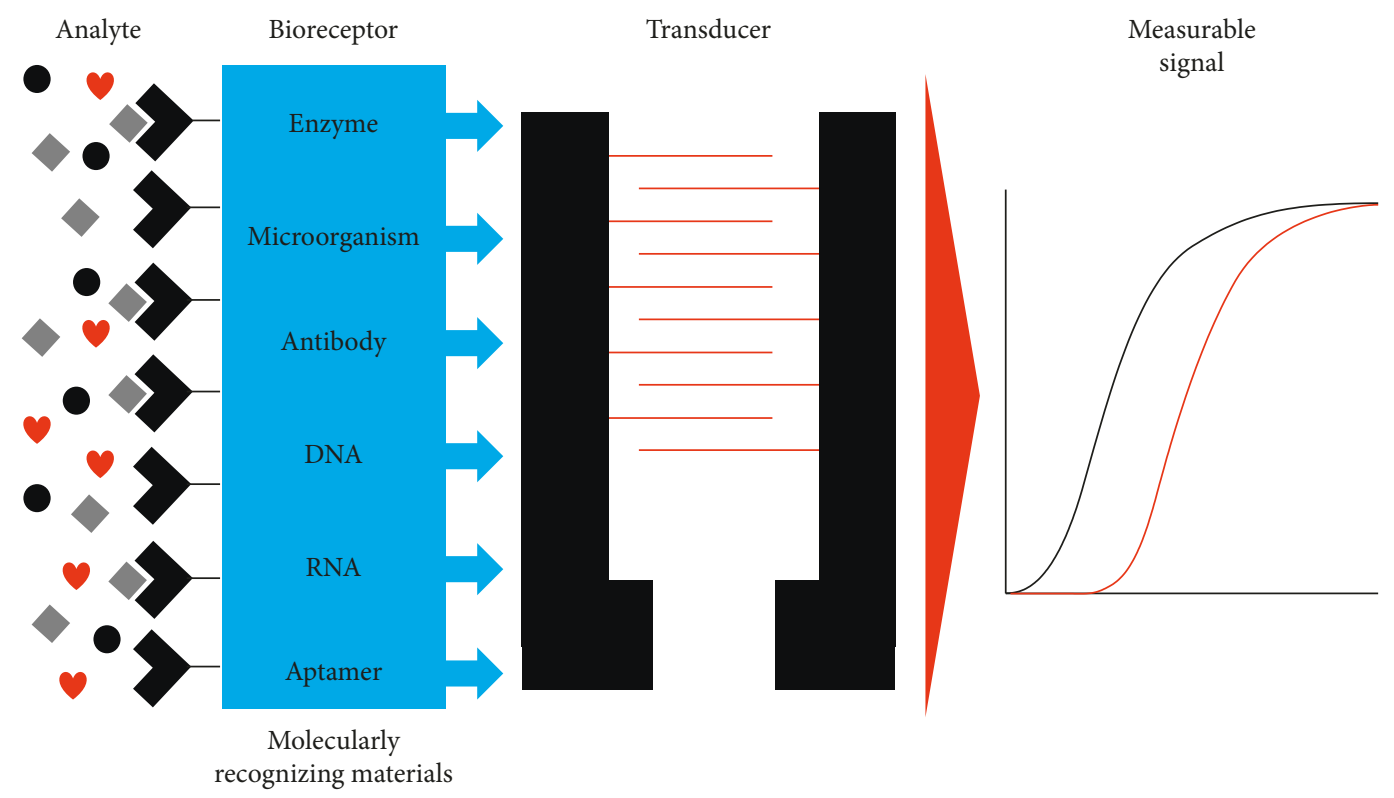

FIGURE 4: Basic principle of the biosensor. Three major portions including analyte, bioreceptor, transducer and measuring system are displayed.

used to quantify the biomarker for cardiac diseases. Along with the sensing system, the appropriate probe for cardiac biomarker is also playing a vital role for early identification. In general antibody, DNA, RNA, and aptamer have been used as the probe to identify the cardiac biomarkers. These probes are more prevalent in the label-free methods such as surface plasmon resonance and dielectric sensors (Figure 5). On the contrary, antibody is also used in the gold-standard labelling enzyme-linked immunosorbent assay (ELISA) for detecting the clinical cardiac biomarkers [44]. There are two types of ELISA, namely, direct and indirect ELISA, which can be referred to detecting the cardiac biomarkers; furthermore, it is also suitable for the conventional sensing surfaces (Figures 6 and 7). Brain natriuretic peptide (BNP) is the neurohormone, widely adopted serological biomarker for analyzing the heart failure. It was proved that a high BNP level is usually found in patients with congestive heart failure. Identifying and quantifying the level of BNP in the blood are mandatory to diagnose the acute heart failure. $\mathrm{N}$-terminal pro-B-type natriuretic peptide (NT-proBNP) is also one of the potential biomarkers for predicting heart failure. Magnetic bead-conjugated BNP with DNA aptamerbased sandwich strategy was used to detect BNP by electrochemiluminescence [45]. A researcher used two aptamers selected against BNP as a capture and reporter to quantify the level of BNP. In addition, it has been found that the elevated troponin $\mathrm{T}$ and troponin I have a significant correlation with cardiac injury. The troponin level in the normal blood is lower; after the onset of myocardial infarction, the level of troponin I is substantially increasing and is possible to measure in blood serum within four to six hours, and the peak concentration of troponin was found in 12 to $24 \mathrm{hrs}$ after myocardial infarction, this will help diagnose the infarction. Detection of troponin at the lower level is

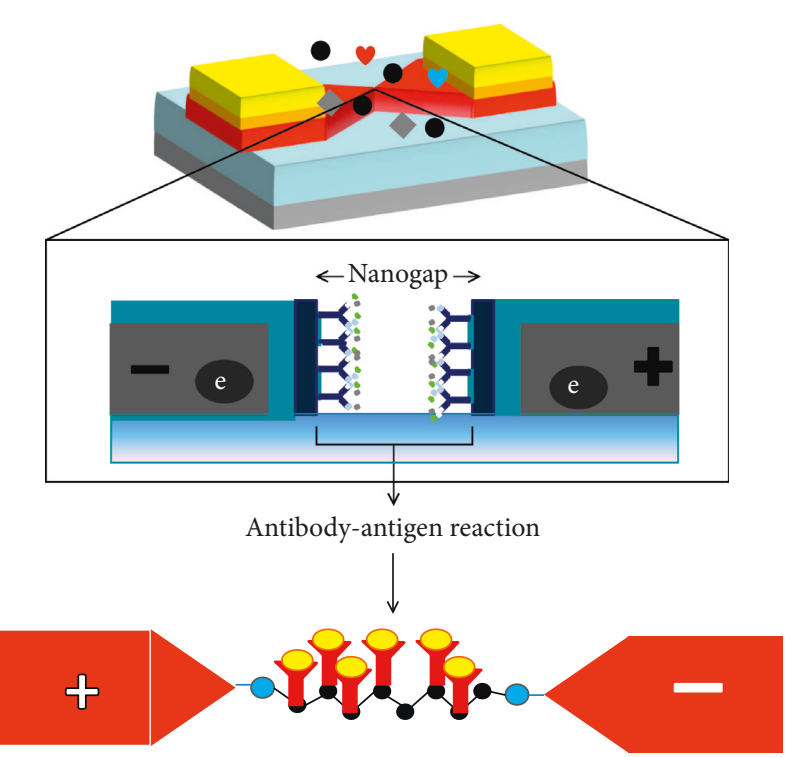

FIGURE 5: A label-free sensor. Interaction of antibody-antigen is shown using the dielectric electrochemical sensor.

mandatory to detect the myocardial infarction at an earlier stage and helps for further treatment. Troponin I was detected on the graphene oxide sheet by the fluorescence quenching method; the 5'-6-FAM-modified troponin aptamer was mixed with different concentrations of troponin; the fluorescence quenching and recovery of the solution were measured at $480 \mathrm{~nm}$, and the detection limit was found as $0.07 \mathrm{ng} / \mathrm{mL}$ [46]. Apart from this method various direct- and indirect-sensing methods with different sensors have been used to identify the cardiac biomarkers for the perioperative period in noncardiac surgery patients. 


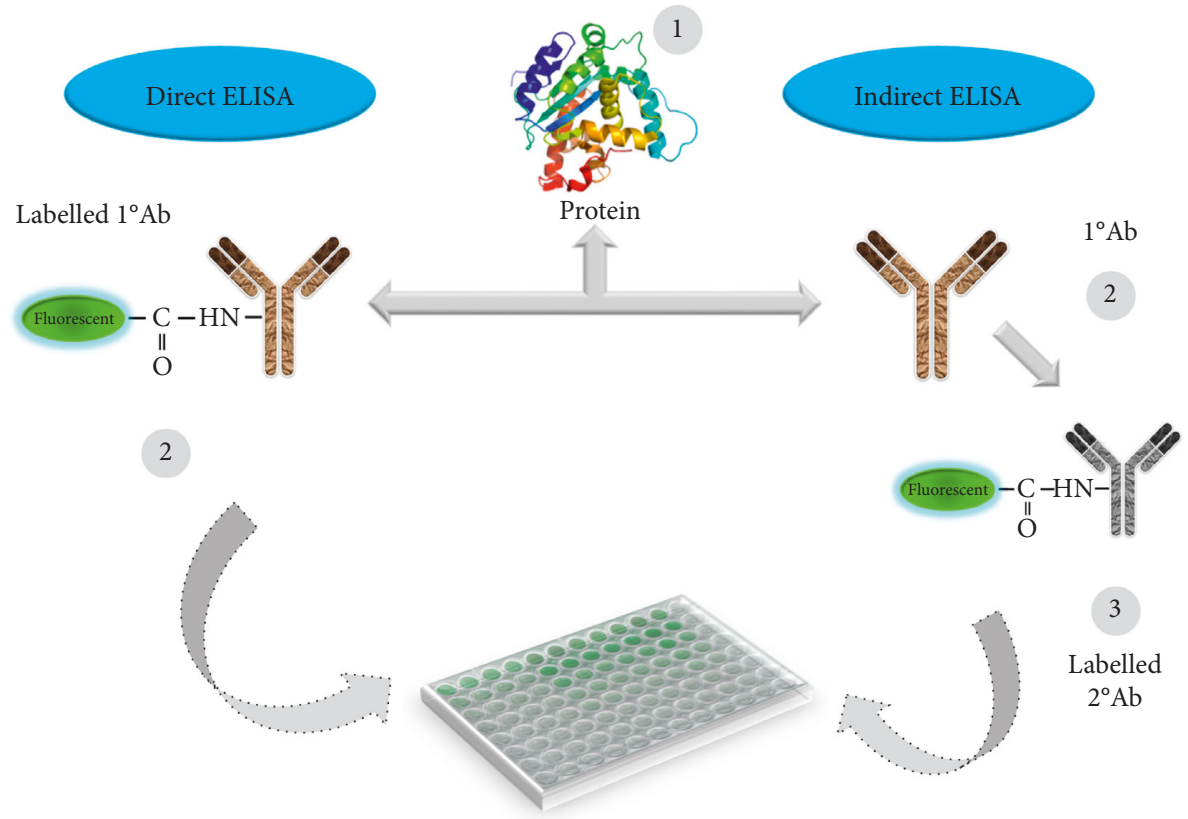

Figure 6: Enzyme-linked immunosorbent assay. Both direct and indirect methods are shown.
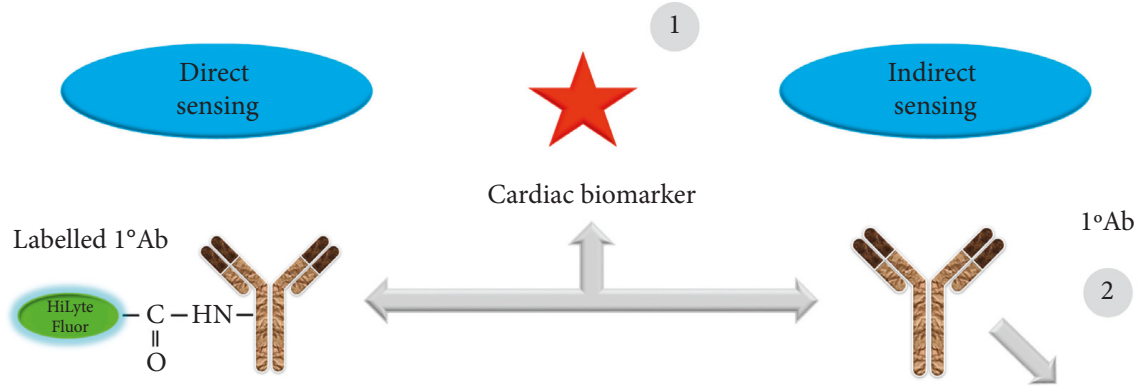

2
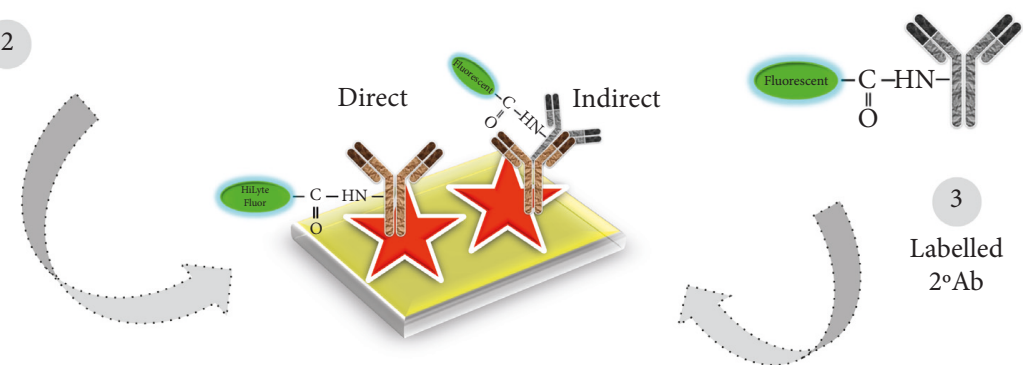

FIGURE 7: Direct and indirect identification methods of cardiac biomarkers by biosensing.

\section{Cardiac Risk Index}

In the past, various cardiac risk indices have been followed and revised the cardiac risk index analysis by the following six variables to check the risk factors of the patients [47]. These include the history of heart failure, ischemic heart disease, stroke, preoperative insulin treatment, transient ischemic attack, and preoperative serum creatinine values $(>152.5 \mathrm{mmol} / \mathrm{l})$. The risk factors and the evaluation methods are summarized in Table $2[47,48]$.

\section{Guidelines and Recommendations}

There were guidelines and recommendations for patients undergoing noncardiac surgery. The Canadian Cardiovascular Society provides the following eight recommendations: (1) measure the level of N-terminal fragment of pro-BNP or brain natriuretic peptides before the surgery of the patients at the age above 65 years and ages from 45 to 64 years with a cardiovascular disease; (2) to enhance the estimation of perioperative cardiac risk, cardiopulmonary exercise testing 
TABle 2: Analyses of cardiovascular risk index: comparison of National Surgical Quality Improvement Program and the Revised Cardiac Risk Index.

\begin{tabular}{|c|c|c|}
\hline Criteria & National Surgical Quality Improvement Program & Revised Cardiac Risk Index \\
\hline Interpretation & $\begin{array}{c}\text { Elevated risk: } \\
2 \text { risk factors: } 7 \% \text { risk; } \\
\geq 3 \text { factors: } 11 \% \text { risk. } \\
\text { Low risk: } \\
0 \text { risk factors: } 0.4 \% \text { risk; } \\
1 \text { risk factor: } 0.9 \% \text { risk }\end{array}$ & $\begin{array}{c}\text { Refer a percent risk from web-based calculator } \\
\text { (http://www.qxmd.com/calculate/calculator_245/ } \\
\text { gupta-perioperative-cardiacrisk) }\end{array}$ \\
\hline Factors used & $\begin{array}{l}\text { History of ischemic heart disease, cerebrovascular } \\
\text { disease, heart disease, serum creatinine level, diabetes } \\
\text { level, condition of undergoing intrathoracic surgery }\end{array}$ & $\begin{array}{l}\text { Serum creatinine } \geq 1.5 \mathrm{mg} / \mathrm{dL} ; \\
\text { age; } \\
\text { surgery type }\end{array}$ \\
\hline Validation and derivation & $\begin{array}{l}\text { Prospective cohort; } \\
\text { single hospital }\end{array}$ & $\begin{array}{c}\text { Historical national database; } \\
\text { multicenter }\end{array}$ \\
\hline Advantages of screening & Used for more than a decade & Surgery-specific \\
\hline Disadvantages of screening & $\begin{array}{c}\text { Functional capacity is not a variable; } \\
\text { advanced procedures such as laparoscopy were not } \\
\text { used; } \\
\text { only } 0.2 \% \text { of patients had severe aortic stenosis }\end{array}$ & $\begin{array}{c}\text { Aortic stenosis and coronary artery disease are not } \\
\text { variables; } \\
\text { due to the elevation of unknown significance, } \\
\text { possibility of over diagnosing myocardial infarctions }\end{array}$ \\
\hline
\end{tabular}

or coronary computed tomography angiography or radionuclide imaging is need to be performed; (3) to be against the continuation or initiation of acetylsalicylic acid in order to prevent the perioperative cardiac event; (4) prior to 24 hrs of surgery, analyze $\beta$-blocker initiation or against $\alpha_{2}$ agonist; (5) maintain the angiotensin-converting enzyme inhibitor and angiotensin II receptor blocker $24 \mathrm{hrs}$ before the surgery being started; (6) mandatory stop with the smoking habit before the surgery to be performed; (7) monitor the daily troponin level for 48-72 hrs after the surgery was carried out in the patients having confirmed higher level of NT-proBNP/BNP before the surgery, especially in the patient who has a Revised Cardiac Risk Index score equal to 1 , aged between 45 and 64 years with an apparent cardiovascular disease, or aged 65 years and above; and (8) preparing for a long-term acetylsalicylic acid and statin therapy in patients suffering from myocardial infarction after the surgery [49].

\section{Monitoring Perioperative Cardiac Risk with Computed Angiography}

Patients with the advanced stages of coronary artery disease during the surgery have increased risk of cardiovascular events [50]. Continuous monitoring is necessary to avoid the risk factors. Coronary computed tomography angiography has been used to evaluate the patients prior to noncardiac surgery. It is a noninvasive well-established technique, which is effectively used to identify the left main and multivessel coronary artery diseases.

\section{Conclusion}

Every year, $\sim 50$ million surgical operations have been performed in the United States; among them, 1.4 to $3.9 \%$ are complicated by a cardiac event. Accurate identification of risk factors is mandatory to reduce the cardiovascular risk especially in the patients aged above 50 years and having the history of cardiac problems. In this review, we discussed the possible cardiac risk factors and the key guidelines during the period of perioperation in the noncardiac surgery patients, and the efficient biomarkers for the cardiac disease diagnosis are discussed. The gleaned information here would help minimize the death rate during the perioperative period of the noncardiac surgery cases. It is important to notice that early identification of cardiac diseases with the suitable biomarkers is mandatory to avoid cardiac risks during the perioperative period.

\author{
Abbreviations \\ CK-MB: $\quad$ Creatine kinase $\mathrm{MB}$ \\ CK: $\quad$ Creatine kinase \\ AST: $\quad$ Aspartate aminotransferase \\ HDBH: $\quad$ Hydroxyl butyrate dehydrogenase \\ LDH: $\quad$ Lactate dehydrogenase \\ TnT: Troponin T \\ TnI: Troponin I \\ CRP: $\quad$ C-reactive protein \\ hsTnT: High-sensitive troponin \\ hFABP: $\quad$ Heart-type fatty acid-binding protein \\ miRNA: microRNA \\ MR- Midregional fragment of proadrenomedullin \\ PAMAP: \\ ELISA: $\quad$ Enzyme-linked immunosorbent assay \\ BNP: $\quad$ Brain natriuretic peptide \\ NT-proBNP: N-terminal pro-B-type natriuretic peptide.
}

\section{Data Availability}

All the data are fully available without restriction.

\section{Conflicts of Interest}

The authors declare that they have no conflicts of interest. 


\section{Authors' Contributions}

Panpan Li and Ying Lei contributed equally to this work. All authors contributed to the preparation of the manuscript and discussion. All authors read and approved the final manuscript.

\section{Acknowledgments}

The authors would like to acknowledge the Servier Medical Art (http://servier.com/Powerpoint-image-bank).

\section{References}

[1] A. Y. Patel, K. A. Eagle, and P. Vaishnava, "Cardiac risk of noncardiac surgery," Journal of the American College of Cardiology, vol. 66, no. 19, pp. 2140-2148, 2015.

[2] W. K. Freeman and R. J. Gibbons, "Perioperative cardiovascular assessment of patients undergoing noncardiac surgery," Mayo Clinic Proceedings, vol. 84, no. 1, pp. 79-90, 2009.

[3] H.-J. Priebe, "Preoperative cardiac management of the patient for non-cardiac surgery: an individualized and evidencebased approach," British Journal of Anaesthesia, vol. 107, no. 1, pp. 83-96, 2011.

[4] J.-W. Hwang, E.-K. Kim, J.-H. Yang et al., "Assessment of perioperative cardiac risk of patients undergoing noncardiac surgery using coronary computed tomographic angiography," Circulation: Cardiovascular Imaging, vol. 8, no. 3, article e002582, 2015.

[5] D. R. J. Collins, A. C. Tompson, I. J. Onakpoya, N. Roberts, A. M. Ward, and C. J. Heneghan, "Global cardiovascular risk assessment in the primary prevention of cardiovascular disease in adults: systematic review of systematic reviews," BMJ Open, vol. 7, no. 3, article e013650, 2017.

[6] D. P. Leong, P. G. Joseph, M. McKee et al., "Reducing the global burden of cardiovascular disease, Part 2," Circulation Research, vol. 121, no. 6, pp. 695-710, 2017.

[7] P. Rattanawong, S. Upala, T. Riangwiwat et al., "Atrial fibrillation is associated with sudden cardiac death: a systematic review and meta-analysis," Journal of Interventional Cardiac Electrophysiology, vol. 51, no. 2, pp. 91-104, 2018.

[8] E. E. K. M. Tjeertes, S. S. E. Hoeks, S. S. B. J. C. Beks, T. T. M. Valentijn, A. A. G. M. Hoofwijk, and R. J. R. J. Stolker, "Obesity-a risk factor for postoperative complications in general surgery?," BMC Anesthesiology, vol. 15, no. 1, p. 112, 2015.

[9] L. A. Fleisher, K. E. Fleischmann, A. D. Auerbach et al., "2014 ACC/AHA guideline on perioperative cardiovascular evaluation and management of patients undergoing noncardiac surgery," Journal of the American College of Cardiology, vol. 64, no. 22, pp. e77-e137, 2014.

[10] B. G. Hammill, L. H. Curtis, E. Bennett-Guerrero et al., "Impact of heart failure on patients undergoing major noncardiac surgery," Anesthesiology, vol. 108, no. 4, pp. 559-567, 2008.

[11] D. Marković, B. Stošić, N. Savić et al., "Importance of biomarkers in preoperative evaluation of cardiovascular risk," Acta Medica Medianae, vol. 55, no. 1, pp. 70-75, 2016.

[12] J. F. Skinner and M. L. Pearce, "Surgical risk in the cardiac patient," Journal of Chronic Diseases, vol. 17, no. 1, pp. 57-72, 1964.

[13] L. Goldman, D. L. Caldera, F. S. Southwick et al., "Cardiac risk factors and complications in non-cardiac surgery," Medicine, vol. 57, no. 4, pp. 357-370, 1978.
[14] L. Goldman, "Cardiac risks and complications of noncardiac surgery," Annals of Internal Medicine, vol. 98, no. 4, pp. 504-513, 1983.

[15] S. Van Diepen, J. A. Bakal, F. A. McAlister, and J. A. Ezekowitz, "Mortality and readmission of patients with heart failure, atrial fibrillation, or coronary artery disease undergoing noncardiac surgery," Circulation, vol. 124, no. 3, pp. 289-296, 2011.

[16] M. S. King, "Preoperative evaluation," American Family Physician, vol. 62, no. 2, pp. 387-396, 2000.

[17] A. Clerico, M. Emdin, and C. Passino, "Cardiac biomarkers and risk assessment in patients undergoing major non-cardiac surgery: time to revise the guidelines?," Clinical Chemistry and Laboratory Medicine, vol. 52, no. 7, pp. 959-963, 2014.

[18] M. Karp, "The importance of preoperative rounds," Anesthesia \& Analgesia, vol. 36, no. 1, pp. 36-40, 1957.

[19] C. Kragelund, B. Grønning, L. Køber, P. Hildebrandt, and R. Steffensen, "N-terminal pro-B-type natriuretic peptide and long-term mortality in stable coronary heart disease," New England Journal of Medicine, vol. 352, no. 7, pp. 666-675, 2005.

[20] B. Zethelius, L. Berglund, J. Sundström et al., "Use of multiple biomarkers to improve the prediction of death from cardiovascular causes," New England Journal of Medicine, vol. 358, no. 20, pp. 2107-2116, 2008.

[21] B. M. Biccard, P. J. Devereaux, and R. N. Rodseth, "Cardiac biomarkers in the prediction of risk in the noncardiac surgery setting," Anaesthesia, vol. 69, no. 5, pp. 484-493, 2014.

[22] S. C. Gibson, A. Marsh, C. Berry et al., "Should pre-operative troponin be a standard requirement in patients undergoing major lower extremity amputation?," European Journal of Vascular and Endovascular Surgery, vol. 31, no. 6, pp. 637641, 2006.

[23] J. Sarveswaran, A. Ikponmwosa, S. Asthana, and J. I. Spark, "Should cardiac troponins be used as a risk stratification tool for patients with chronic critical limb ischaemia?," European Journal of Vascular and Endovascular Surgery, vol. 33, no. 6, pp. 703-707, 2007.

[24] R. Janković, D. Marković, N. Savić, and V. Dinić, "Beyond the limits: clinical utility of novel cardiac biomarkers," BioMed Research International, vol. 2015, Article ID 187384, 8 pages, 2015.

[25] M. F. M. Fathil, M. K. Md Arshad, A. R. Ruslinda et al., "Substrate-gate coupling in ZnO-FET biosensor for cardiac troponin I detection," Sensors and Actuators B: Chemical, vol. 242, pp. 1142-1154, 2017.

[26] M. F. M. Fathil, M. K. Md Arshad, A. R. Ruslinda et al., "Progression in sensing cardiac troponin biomarker charge transductions on semiconducting nanomaterials," Analytica Chimica Acta, vol. 935, pp. 30-43, 2016.

[27] M. K. M. Arshad, R. Adzhri, M. F. M. Fathil, S. C. B. Gopinath, and M. N. M. Nuzaihan, "Field-effect transistor-integration with $\mathrm{TiO}_{2}$ nanoparticles for sensing of cardiac troponin I biomarker," Journal of Nanoscience and Nanotechnology, vol. 18, no. 8, pp. 5283-5291, 2018.

[28] M. Khairuddin Md Arshad, M. Faris Bin Mohamad Fathil, S. C. B. Gopinath et al., "Cardiac biomarkers: invasive to noninvasive assessments," Current Medicinal Chemistry, vol. 23, no. 37, pp. 4270-4284, 2016.

[29] K. R. Seferian, N. N. Tamm, A. G. Semenov et al., "The brain natriuretic peptide (BNP) precursor is the major immunoreactive form of BNP in patients with heart failure," Clinical Chemistry, vol. 53, no. 5, pp. 866-873, 2007. 
[30] M. Negahdary, M. Behjati-Ardakani, N. Sattarahmady, and H. Heli, "An aptamer-based biosensor for troponin I detection in diagnosis of myocardial infarction," Journal of Biomedical Physics \& Engineering, vol. 8, no. 2, pp. 167-178, 2018.

[31] N. R. Shanmugam, S. Muthukumar, A. S. Tanak, and S. Prasad, "Multiplexed electrochemical detection of three cardiac biomarkers cTnI, cTnT and BNP using nanostructured ZnO-sensing platform," Future Cardiology, vol. 14, no. 2, pp. 131-141, 2018.

[32] W. Wang, Z. Mai, Y. Chen et al., "A label-free fiber optic SPR biosensor for specific detection of C-reactive protein," Scientific Reports, vol. 7, p. 16904, 2017.

[33] B. Wu, R. Jiang, Q. Wang et al., "Detection of C-reactive protein using nanoparticle-enhanced surface plasmon resonance using an aptamer-antibody sandwich assay," Chemical Communications, vol. 52, no. 17, pp. 3568-3571, 2016.

[34] I. Letchumanan, M. K. Md Arshad, S. R. Balakrishnan, and S. C. B. Gopinath, "Gold-nanorod enhances dielectric voltammetry detection of c-reactive protein: a predictive strategy for cardiac failure," Biosensors and Bioelectronics, vol. 130, pp. 40-47, 2019.

[35] M. M. Rahman, M. J. A. Shiddiky, M. A. Rahman, and Y.-B. Shim, "A lactate biosensor based on lactate dehydrogenase/nictotinamide adenine dinucleotide (oxidized form) immobilized on a conducting polymer/multiwall carbon nanotube composite film," Analytical Biochemistry, vol. 384, no. 1, pp. 159-165, 2009.

[36] I. Sarangadharan, A. Regmi, Y.-W. Chen et al., "High sensitivity cardiac troponin I detection in physiological environment using AlGaN/GaN High Electron Mobility Transistor (HEMT) Biosensors," Biosensors and Bioelectronics, vol. 100, pp. 282-289, 2018.

[37] C. C. Ong, S. C. B. Gopinath, L. W. X. Rebecca, V. Perumal, T. Lakshmipriya, and M. S. M. Saheed, "Diagnosing human blood clotting deficiency," International Journal of Biological Macromolecules, vol. 116, pp. 765-773, 2018.

[38] A. A. Odeh, Y. Al-Douri, C. H. Voon et al., "A needle-like $\mathrm{Cu}_{2} \mathrm{CdSnS}_{4}$ alloy nanostructure-based integrated electrochemical biosensor for detecting the DNA of Dengue serotype 2," Microchimica Acta, vol. 184, no. 7, pp. 2211-2218, 2017.

[39] C. Ibau, M. K. Md Arshad, and S. C. B. Gopinath, "Current advances and future visions on bioelectronic immunosensing for prostate-specific antigen," Biosensors and Bioelectronics, vol. 98, pp. 267-284, 2017.

[40] A. S. Ibraheam, Y. Al-Douri, C. H. Voon et al., "Surface functionalized Cu2Zn1-x Cd x SnS4 quinternary alloyed nanostructure for DNA sensing," Applied Physics A, vol. 123, no. 3, p. 200, 2017.

[41] A. Sudarvizhi, K. Pandian, O. S. Oluwafemi, and S. C. B. Gopinath, "Amperometry detection of nitrite in food samples using tetrasulfonated copper phthalocyanine modified glassy carbon electrode," Sensors and Actuators B: Chemical, vol. 272, pp. 151-159, 2018.

[42] B. Ranjani, J. Kalaiyarasi, L. Pavithra, T. Devasena, K. Pandian, and S. C. B. Gopinath, "Amperometric determination of nitrite using natural fibers as template for titanium dioxide nanotubes with immobilized hemin as electron transfer mediator," Microchimica Acta, vol. 185, no. 3, 2018.

[43] J. Kalaiyarasi, S. Meenakshi, S. C. B. Gopinath, and K. Pandian, "Mediator-free simultaneous determination of acetaminophen and caffeine using a glassy carbon electrode modified with a nanotubular clay," Microchimica Acta, vol. 184, no. 11, pp. 4485-4494, 2017.

[44] T. Lakshmipriya, S. C. B. Gopinath, and T.-H. Tang, "Biotinstreptavidin competition mediates sensitive detection of biomolecules in enzyme linked immunosorbent assay," PLoS One, vol. 11, no. 3, Article ID e0151153, 2016.

[45] J. G. Bruno, A. M. Richarte, and T. Phillips, "Preliminary development of a DNA aptamer-magnetic bead capture electrochemiluminescence sandwich assay for brain natriuretic peptide," Microchemical Journal, vol. 115, pp. 32-38, 2014.

[46] D. Liu, X. Lu, Y. Yang, Y. Zhai, J. Zhang, and L. Li, “A novel fluorescent aptasensor for the highly sensitive and selective detection of cardiac troponin I based on a graphene oxide platform," Analytical and Bioanalytical Chemistry, vol. 410, no. 18, pp. 4285-4291, 2018.

[47] T. H. Lee, E. R. Marcantonio, C. M. Mangione et al., "Derivation and prospective validation of a simple index for prediction of cardiac risk of major noncardiac surgery," Circulation, vol. 100, no. 10, pp. 1043-1049, 1999.

[48] P. K. Gupta, H. Gupta, A. Sundaram et al., "Development and validation of a risk calculator for prediction of cardiac risk after surgery," Circulation, vol. 124, no. 4, pp. 381-387, 2011.

[49] E. Duceppe, J. Parlow, P. MacDonald et al., "Canadian cardiovascular society guidelines on perioperative cardiac risk assessment and management for patients who undergo noncardiac surgery," Canadian Journal of Cardiology, vol. 33, no. 1, pp. 17-32, 2017.

[50] J. L. Furgerson, "Perioperative cardiovascular evaluation: is there a role for coronary computed tomography angiography?," Journal of the American Osteopathic College of Radiology, vol. 2, no. 2, pp. 8-13, 2013. 

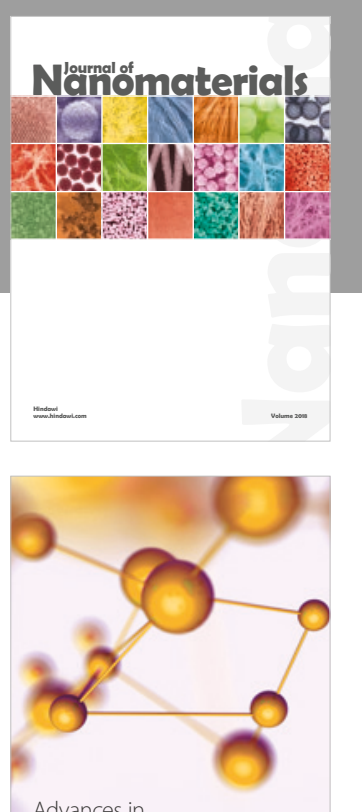

Physical Chemistry
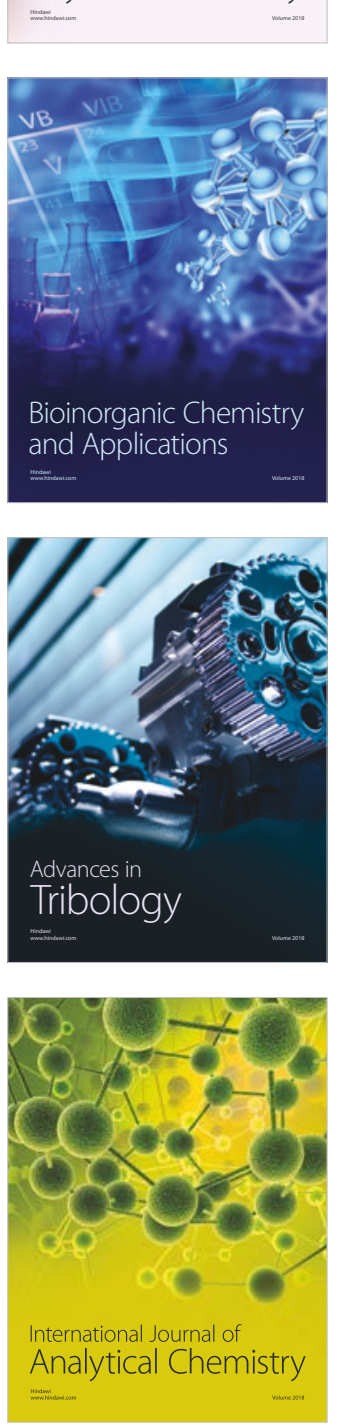

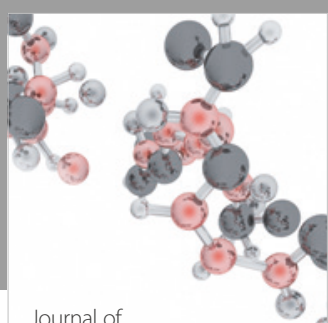

Analytical Methods

in Chemistry

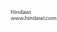

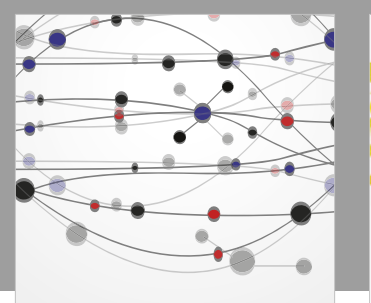

The Scientific World Journal

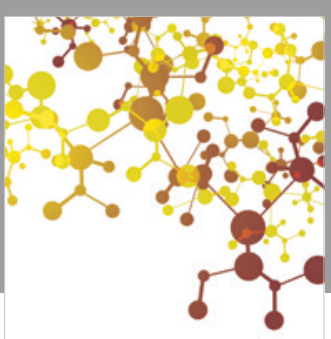

Journal of

Applied Chemistry
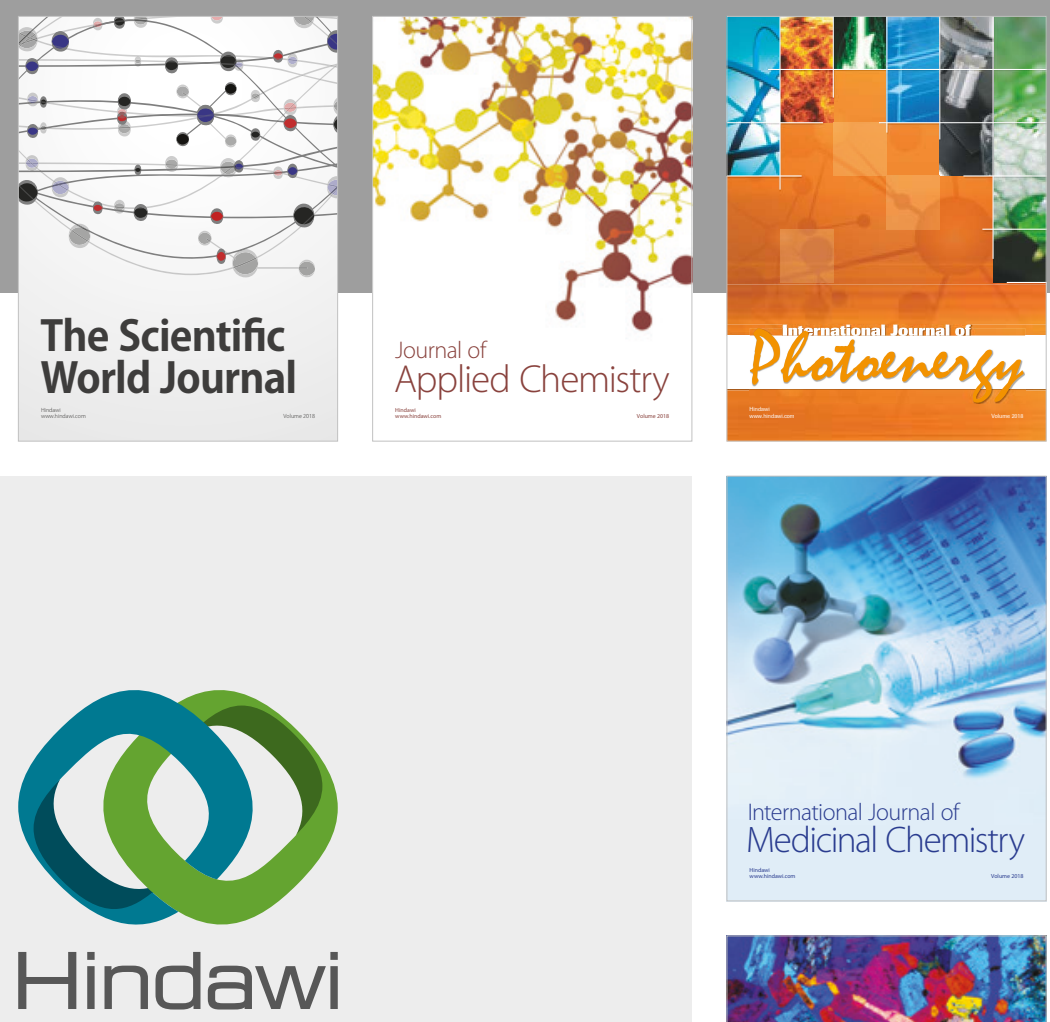

Submit your manuscripts at

www.hindawi.com
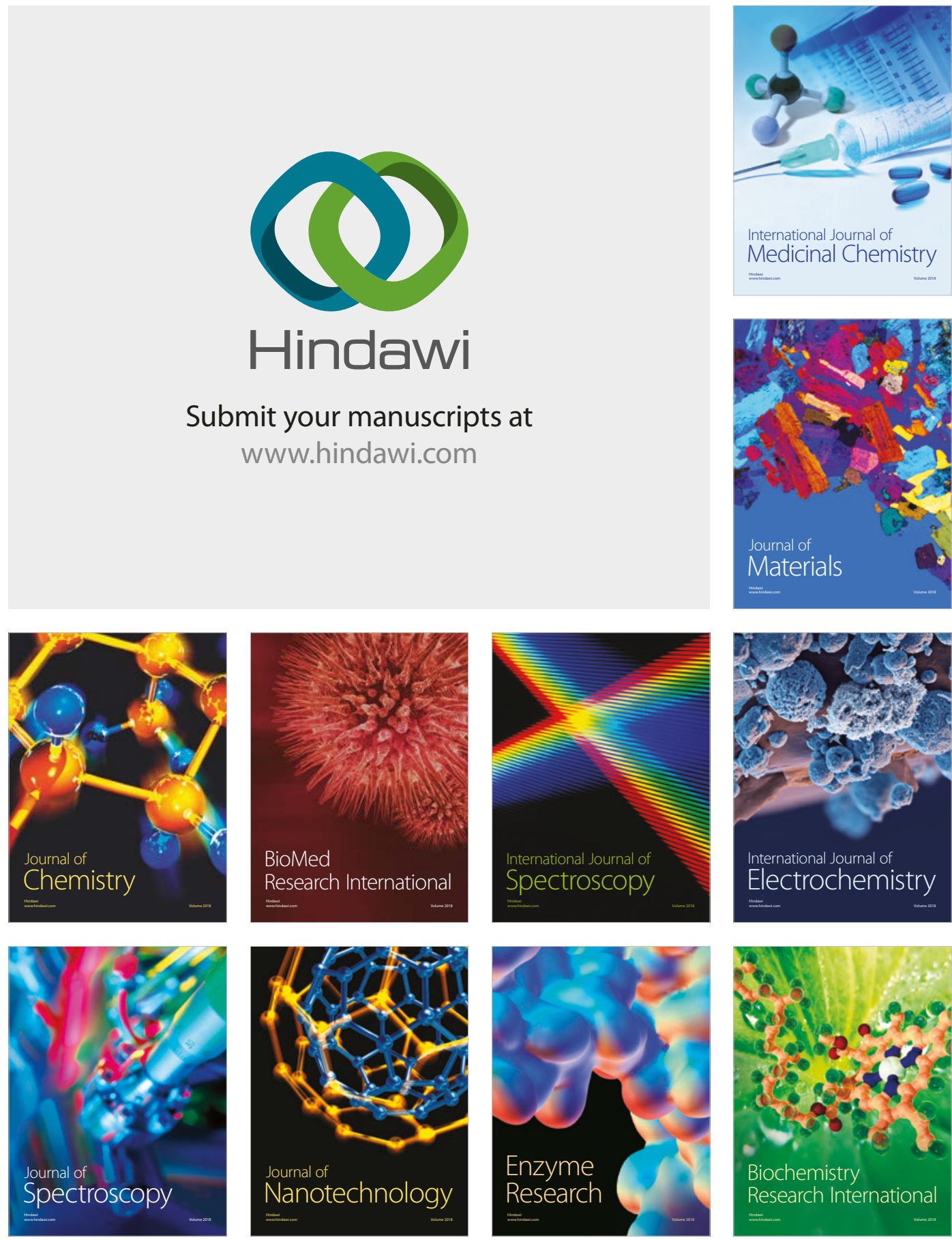
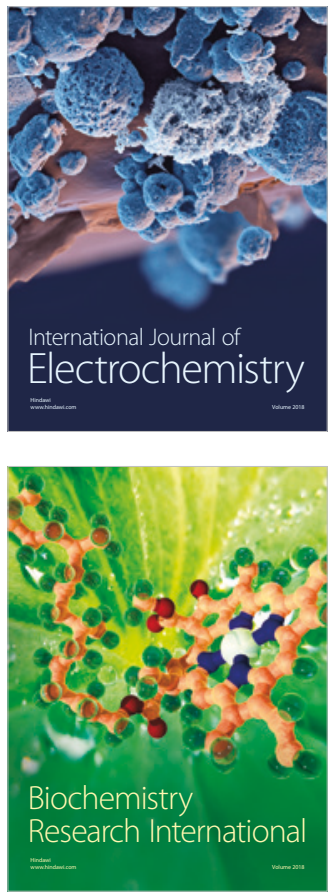